$\mathbb{T}$ periodica polytechnica

Chemical Engineering

57/1-2 (2013) 41 51

doi: $10.3311 /$ PPch.2169

http://periodicapolytechnica.org/ch

Creative Commons Attribution (i)

RESEARCH ARTICLE

\section{Hydrogen peroxide oxidation for in situ remediation of trichloroethylene - from the laboratory to the field}

\author{
Ildikó Fekete-Kertész / Mónika Molnár / Ágota Atkári / Katalin Gruiz / Éva Fenyvesi
}

Received 2012-04-26, accepted 2013-02-20

\begin{abstract}
In this paper we present the remediation possibilities of a trichloroethylene contaminated site of a former metalworking plant in Hungary, where high TCE concentration $(150 \mu \mathrm{g} / \mathrm{L}$ to $35.000 \mu \mathrm{g} / \mathrm{L})$ was detected in the groundwater. Lab-scale experiments were performed to compare the potential bioremediation technology-alternatives eg.: enhanced biodegradation; pump \& treat by UV irradiation (photodegradation); in situ chemical oxidation (ISCO) applying different oxidants ( $\mathrm{KMnO}_{4}$, $\mathrm{Na}_{2} \mathrm{~S}_{2} \mathrm{O}_{8}$ and $\mathrm{H}_{2} \mathrm{O}_{2}$ ). The lab-scale experiments showed in all cases reduction of the TCE-concentration of the water. Comparing the removal efficacy and concerning the time requirement ISCO was the most effective in laboratory studies.
\end{abstract}

\section{Keywords}

chlorinated hydrocarbons $\cdot$ cometabolism $\cdot$ cyclodextrin $\cdot$ in situ chemical oxidation (ISCO) · photodegradation · remediation $\cdot$ trichlororethylene $(T C E)$

\section{Acknowledgement}

The research was supported by Anyos Jedlik Hungarian National Research and Technology Programme (MOKKA NKFP-300020/2005). The technical assistance of Borbála Bátai, Klára Balogh, Péterné Csabai, Zsófia Fehér, Norbert Lantos, Csaba Molina and Eszter Oláh in the bench scale experiments and in the analysis of field samples is greatly acknowledged.

\section{Ildikó Fekete-Kertész}

Mónika Molnár

Budapest University of Technology and Economics, Dept. of Applied Biotechnology and Food Science, Gellért square 4., Budapest, H-1111, Hungary

\section{Ágota Atkári}

WEPROT Ltd., Soroksári str. 18, Budapest, H-1095, Hungary

\section{Katalin Gruiz}

Budapest University of Technology and Economics, Dept. of Applied Biotechnology and Food Science, Gellért square 4., Budapest, H-1111, Hungary

\section{Éva Fenyvesi}

Cyclolab Cyclodextrin R\&D Laboratory Ltd., Illatos str. 7, Budapest, H-1097, Hungary

\section{Introduction}

At many industrial sites, chlorinated solvents in soils and aquifers impose potential threats to groundwater and human health. Chlorinated aliphatic hydrocarbons, such as trichloroethylene are also among the most difficult contaminants to remove, particularly when their dense non-aqueous-phase liquid (DNAPL) sources remain in the subsurface. Advanced oxidation processes, such as in situ chemical oxidation (ISCO) is a remediation technology that proved to be effective in treating soils and groundwater matrices contaminated with organic pollutants, such as chlorinated solvents [1-6]. In situ chemical oxidation is based on the introduction of a chemical oxidant into the subsurface for transforming contaminants in soil and ground-water into less harmful chemical substances. Several different forms of oxidants have been commonly used for ISCO, e.g. permanganate $\left(\mathrm{MnO}_{4}^{-}\right)$, hydrogen peroxide $\left(\mathrm{H}_{2} \mathrm{O}_{2}\right)$ and iron ( $\mathrm{Fe}$ ) (Fenton-driven, or $\mathrm{H}_{2} \mathrm{O}_{2}$-derived oxidation [7.-9], persulfate $\left(\mathrm{S}_{2} \mathrm{O}_{8}^{2-}\right)$, and ozone $\left(\mathrm{O}_{3}\right)[10]$.

Fenton's system was applied to the destruction of perchloroethylene (PCE) present in soil slurry systems. Studies were conducted in two matrices: soil and sand. In the sand a $60-62 \%$ decrease of PCE concentration was observed, and $\mathrm{Cl}^{-}$recovery was $47-58 \%$, whereas in soil a $44-49 \%$ decrease in PCE concentration and a $\mathrm{Cl}^{-}$recovery of $40-42 \%$ were observed after the addition of $600 \mathrm{mM} \mathrm{H}_{2} \mathrm{O}_{2}$ and $10 \mathrm{mM}$ dissolved iron [11]. Hydrogen peroxide at low concentrations $(<0.1 \%)$ is not kinetically fast enough to degrade many hazardous organic contaminants before decomposition. The addition of iron(II) a ferrous salt dramatically increases the oxidative strength of peroxide, this process is called Fenton reaction [12].

Under batch experimental conditions and low $\mathrm{pH}$ values Fenton's reagent was able to oxidize $93-100 \%$ (by weight) of dissolved TCE in groundwater and $98-102 \%$ (by weight) of TCE in soil slurries. Fenton's reagent was able to completely dechlorinate the aqueous-phase TCE with and without the presence of soil so that no VOC intermediates or by-products were found in the oxidation process [13].

The effects of $\mathrm{H}_{2} \mathrm{O}_{2}$ and $\mathrm{O}_{3}$ on the decomposition of trichloroethylene (TCE) and perchloroethylene (PCE) by 
gamma-rays ( $\gamma$-rays) were investigated. The results show that $\gamma$-rays cannot dissociate $\mathrm{H}_{2} \mathrm{O}_{2}$ to produce hydroxyl radicals, so this does not cause the increase of TCE and PCE removals however, enhanced $\mathrm{O}_{3}$ decomposition caused by gamma radiation provides additional hydroxyl radicals, and this phenomenon accelerates the removal of TCE and PCE. Because of these synergistic effects, the combined $\gamma$-rays $/ \mathrm{O}_{3}$ method can be a promising technique for TCE and PCE removal in groundwater [14]. It was also found, that $\mathrm{H}_{2} \mathrm{O}_{2}$ based ISCO is a cost effective and feasible solution for the elimination of TCE contamination from water matrices and soil [15].

For TCE elimination iron activated persulfate treatment, thermally activated persulfate treatment and hydroxypropyl-betacyclodextrin-mediated iron-activated persulfate treatment are feasible processes, in which an ISCO oxidant, persulfate anion $\left(\mathrm{S}_{2} \mathrm{O}_{8}^{2-}\right)$ can be also activated by ferrous ion $\left(\mathrm{Fe}^{2+}\right)$ to generate sulfate radicals, which are capable of destroying trichloroethylene (TCE) [16-20].

Many studies investigate whether ISCO has got an effect on the microbial communities. The results indicate that although microbial communities may potentially be affected by ISCO on the short term, a rebound of bioremediation and microbial biomass can be detected. ISCO can be coupled successfully with bioremediation in field applications and it may be a costeffective method for achieving risk-based site remediation goals [6].

In case of in situ biological oxidation (ISB) a biological process is used to convert contaminants into less hazardous byproducts. It is one of the most effective methods for eliminating many organic compounds, besides it is the most cost-effective treatment available nowadays [21,22].

Numerous environmental pollutants, such as chlorinated solvents and fuel derivatives have been shown to be degraded by aerobic and anaerobic microbial processes. Many carbon- based pollutants can be degraded in aerobic systems however; some of these processes are cometabolic. Cometabolism is the transformation of an organic compound in a metabolic process in which an organic compound is converted into different metabolic products by the induction of enzymes but does not serve as a source of energy or carbon to the microorganism [6]. For many recalcitrant contaminants it is a useful option to initiate the degradation.

Increased biomass and decreased diversity were measured [23], although many researchers measured rebound in microbial biomass/activity and decreased cell concentration in case of catalyzed hydrogen peroxide (CHP) [4, 24, 26]. Slight positive effect was found on the microbial biomass [27-29], although others found negative effect of $\mathrm{KMnO}_{4}$ on the microbial biomass [30-32].

In situ chemical oxidation has also been shown to enhance microbial activity by increasing substrate availability. Preoxidation of recalcitrant compounds with $\mathrm{CHP}, \mathrm{KMnO}_{4}$, and $\mathrm{O}_{3}$ to enhance biodegradation activity by oxidizing organic molecules into bioavailable substrates has been used for years in bioremediation processes [33-41].

The factors affecting cost and performance of remediation technologies differ from site to site. Because of this in case of most applications laboratory and pilot-scale feasibility studies should be performed to ensure successful full-scale implementation. Bench-scale experiments were performed on TCEspiked water and soil as well as on contaminated ground-water and soil originated from the polluted site. Later on pilot tests were planned and carried out on the site based on the results of laboratory experiments and site assessment.

\section{Materials and methods}

High chlorinated aliphatic hydrocarbon (mainly trichloroethylene) concentrations were detected in the groundwater of a former metalworking plant site in Hungary. Lab-scale experiments were conducted to compare the potential remediation technology-alternatives. Different remediation technologies were modelled and evaluated in the lab after detailed assessment of the site. TCE-spiked model solution and contaminated groundwater and soil from the site were treated with different technologies.

Two situations were tested: dissolved contaminants in groundwater and underground lenses functioning as continuous sources.

Soil and ground-water samples were taken from a former metal manufacturing plant site in Western Hungary where TCE was used for degreasing of metal parts.

\subsection{Materials}

Random methylated $\beta$-cyclodextrin (RAMEB, degree of methylation is 12) was the product of Wacker Chemie (Munich, Germany).

All chemicals used were reagent grade purchased from Sigma-Aldrich: trichloroethylene (TCE, $\geq 99.5 \%$ ), potassium permanganate $\left(\mathrm{KMnO}_{4}, \geq 99 \%\right)$, sodium persulfate $\left(\mathrm{Na}_{2} \mathrm{~S}_{2} \mathrm{O}_{8}\right.$, $\geq 98 \%$ ), sodium thiosulfate $\left(\mathrm{Na}_{2} \mathrm{~S}_{2} \mathrm{O}_{3}, 99 \%\right)$, hydrogen peroxide solution $\left(30 \%(\mathrm{w} / \mathrm{w}) \mathrm{H}_{2} \mathrm{O}_{2}\right)$, iron(II) sulphate $(\geq 99 \%$, $\left.\mathrm{FeSO}_{4} \cdot 7 \mathrm{H}_{2} \mathrm{O}\right)$

\subsection{Experimental}

\subsubsection{Laboratory feasibility studies}

\subsubsection{Bioremediation based on cometabolic biodegrada-} tion of TCE using additives

Cometabolic biodegradation of trichloroethylene in the presence of toluene as a growth substrate was modelled in batch reactors. The effect of randomly methylated $\beta$-cyclodextrin (RAMEB) on biodegradation of TCE was also tested. Cyclodextrins are able to solubilise chlorinated aliphatic hydrocarbons and to enhance the efficacy of the remediation technologies [42-45].

In our model experiment $450 \mathrm{~mL}$ groundwater $(\mathrm{GW})$ originated from the site contaminated with TCE $(2.13 \mathrm{mg} / \mathrm{L})$ was 
placed into $500 \mathrm{~mL}$ glass reactors. Then $292 \mathrm{mg} / \mathrm{L}$ concentration TCE was added to all reaction bottles. After that reactors were supplied with toluene $(500 \mathrm{mg} / \mathrm{L}, 1000 \mathrm{mg} / \mathrm{L})$ or with RAMEB at $0.5 \%$ or $1.0 \%(\mathrm{w} / \mathrm{w})$ concentration. Control tests were carried out without these additives. The reactors were shaken at 100 rpm in the dark at $20{ }^{\circ} \mathrm{C}$. Samples were withdrawn after 10 days and the TCE-degrading cell number; the concentration of $\mathrm{Cl}^{-}$ ions, as well as TCE concentration was measured.

\subsubsection{Pump \& treat combined with UV irradiation - pho- todegradation of TCE}

In this experiment the UV irradiation intensified by cyclodextrin addition was modelled at lab-scale. Cyclodextrins are able to solubilise chlorinated aliphatic hydrocarbons and to enhance the efficacy of the remediation technologies.

Extraction experiments modelling pump $\mathcal{E}$ treat $(\mathrm{P} \& \mathrm{~T})$ were performed prior to UV irradiation with different concentrations of cyclodextrin solution. For extraction of TCE 0, 5, 10 and $20 \%$ aqueous cyclodextrin solutions of randomly methylated $\beta$ cyclodextrin (RAMEB) were applied. The extraction technology was modelled by introducing a TCE lens $(10 \mathrm{~mL})$ under $200 \mathrm{~mL}$ of groundwater originated from the site. The groundwater was amended by cyclodextrin as solubilising agent. These solutions were periodically shaken $(10 \mathrm{~min} / \mathrm{h})$ for 3 days and the concentration of TCE was measured by gas chromatography (GC). For modelling photodegradation by UV irradiation $3 \mathrm{~mL}$ of supernatant from the extraction experiments was transferred into a quartz cuvette then irradiated for 90 minutes with high pressure mercury lamp (500 W). Samples were taken at every 5 minutes. The TCE content was measured by GC after dilution with dimethyl formamide (DMF). Experiments were carried out in two parallels.

\subsubsection{In situ chemical oxidation (ISCO) applying different oxidants such as sodium persulfate, potassium perman- ganate and hydrogen peroxide}

Site-specific conditions and parameters, in conjunction with oxidant specific characteristics, strengths, weaknesses and limitations of the technology must be carefully considered before field-scale implementation to determine whether ISCO is a feasible option, and to determine which oxidant is the most appropriate. All of the applied oxidants $\left(\mathrm{KMnO}_{4}, \mathrm{Na}_{2} \mathrm{~S}_{2} \mathrm{O}_{8}, \mathrm{H}_{2} \mathrm{O}_{2}\right)$ which are commonly used for the ISCO have many advantageous but they have drawbacks and disadvantageous effects at the same time.

ISCO with sodium persulfate of the contaminated groundwater

In situ chemical oxidation of contaminated groundwater using sodium persulfate was modelled in batch reactors. In our model experiment $250 \mathrm{~mL}$ groundwater samples originated from the site supplied with $100 \mathrm{mg} / \mathrm{L}$ TCE were placed into $250 \mathrm{~mL}$ volume glass reactors shielded from light. Then sodium persulfate was added to all reaction bottles to attain fi- nal $\mathrm{Na}_{2} \mathrm{~S}_{2} \mathrm{O}_{8}$ concentrations of 18 and $36 \mathrm{~g} / \mathrm{L}$ (10-times and 20times molar excess relative to the chlorine in TCE). The influence of ferrous ions on the activation of persulfate to produce a powerful oxidant known as sulphate free radicals was also examined with the addition of $\mathrm{FeSO}_{4}(1.1$ and $2.2 \mathrm{~g} / \mathrm{L})$.

ISCO with potassium permanganate of the contaminated groundwater

The lab-scale batch experiments with potassium permanganate were also performed in $250 \mathrm{~mL}$ glass vessels. The groundwater $(250 \mathrm{~mL})$ was supplied with $100 \mathrm{mg} / \mathrm{L}$ or $1000 \mathrm{mg} / \mathrm{L}$ TCE and treated with potassium permanganate at the concentrations of $0.12 \mathrm{~g} / \mathrm{L}$ and $0.6 \mathrm{~g} / \mathrm{L}$ in the case of $100 \mathrm{mg} / \mathrm{L}$ TCE, and with $1.2 \mathrm{~g} / \mathrm{L}$ and $6 \mathrm{~g} / \mathrm{L}$ permanganate in the case of $1 \mathrm{~g} / \mathrm{L}$ TCE, respectively.

ISCO with hydrogen peroxide of the contaminated groundwater

Batch experiments with hydrogen peroxide were conducted in $250 \mathrm{~mL}$ glass vessels. The groundwater $(250 \mathrm{~mL})$ taken from the site was supplied with $1000 \mathrm{mg} / \mathrm{L}$ TCE and treated with $0.3 \%$ and $0.9 \%$ hydrogen peroxide. The effectiveness of the chemical oxidation using $\mathrm{H}_{2} \mathrm{O}_{2}$ was improved by addition of phosphoric acid $(0.1-0.2 \%)$ to ensure the necessary acidic $\mathrm{pH}$. The initial $\mathrm{pH}$ level was controlled at $3 \pm 0.1$. Ferrous ion was used as a catalyst in the experiments with the addition of $\mathrm{FeSO}_{4} \cdot 7 \mathrm{H}_{2} \mathrm{O}$ $(11 \mathrm{~g} / \mathrm{L})$.

Control tests were also carried out with groundwater without additives in all of lab-scale ISCO experiments. Effects of the oxidants were studied in three parallels in all of the cases. The reactors were shaken at $100 \mathrm{rpm}$ in the dark. Samples were withdrawn after 24 hours and the $\mathrm{Cl}^{-}$, conductivity as well as TCE concentration was measured.

ISCO with hydrogen peroxide of the saturated soil in static reactor

In our model set-up $300 \mathrm{~g}$ soil originated from the site was saturated with $300 \mathrm{~mL}$ groundwater contaminated with TCE at $1 \mathrm{~g} / \mathrm{L}$ concentration in static batch $1000 \mathrm{~mL}$ reactor. The reactors were supplied with $50 \mathrm{~mL} \mathrm{H}_{2} \mathrm{O}_{2}$ solution to have final $\mathrm{H}_{2} \mathrm{O}_{2}$ concentrations of $0.5 \%, 1 \%$ and $2 \%$ in the reactors. Control reactors without TCE-supplement and peroxide-addition were also prepared.

Reactors were placed in a dark room for 15 days at $20^{\circ} \mathrm{C}$. Samples were withdrawn after 15 days and the $\mathrm{pH}, \mathrm{Cl}^{-}$and residual TCE was measured. Microbial activity (aerobic and anaerobic heterotrophic cells, dehydrogenase enzyme activity) in the soils was also determined.

\subsubsection{Pilot scale demonstration of ISCO using hydrogen peroxide in the field}

Site description and history of the site

The site selected for pilot scale experiments and demonstration is located at the western part of Hungary. It has been an industrial site for long time where trichloroethylene (TCE) was used earlier for metal degreasing. The soil and groundwater 
have been contaminated for decades. TCE as the main contaminant was identified.

The regulatory limits in the groundwater for each of volatile chlorinated hydrocarbons (VCHs) and for the total volatile hydrocarbons have been set to $0.15 \mathrm{mg} / \mathrm{L}$ and $0.3 \mathrm{mg} / \mathrm{L}$ (Hungarian Remediation Limit Value $(D)$ for the TCE: $D=$ $0.15 \mathrm{mg} / \mathrm{L}$ in the groundwater of the site). As part of remedial actions the most contaminated soil was removed to a landfill site and the groundwater decontamination system (extraction and monitoring wells, stripping tower) was built. Air stripping was used to remove the volatile chlorinated compounds from groundwater. The technology has operated for 3 years but it failed to reduce the TCE content in the wells to the limit value. The technology proved not to be suitable to remove the waterinsoluble VCHs.

Assessment of the site 26 monitoring wells were established at the site and the extent of contamination was determined. TCE as the main contaminant was identified. Some other chlorinated ethylenes such as tetrachlorethylene, PCE and dichloroethylene isomers, DCE as well as chlorinated ethanes were detected at lower concentrations. In some wells also vinyl chloride was found suggesting microbiological degradation. TCE lenses were suspected on the site, these sources contaminated the groundwater from time to time. The contaminated area was delineated as shown on the maps in Figure 1 .

As part of the site assessment the activity of the soil- and ground water microflora was also investigated. The microbial activity was characterized by the aerobic heterotrophic cell concentration and by the aerobic and anaerobic TCE-degrading cell concentration. The latter was found high enough to assume that there is a microbial consortium able to degrade TCE; therefore the bioremediation as a technology alternative was also taken into consideration. Direct contact toxicity tests were done to assess and evaluate the risks of the contaminated soil and groundwater.

Pilot test applying hydrogen peroxide oxidation combined with alternate pumping

Before applying the pilot tests a new well (M-3) was bored in the direction of the hydraulic gradient between the assumed source and the extracting well MTE-1. (See the map in Figure2. In the pilot test alternating pumping was used involving MTE-1 and M-3 wells: while pumping the water from one of the wells the other one was left undisturbed. This method is a mixture of "push \& pull" (the groundwater is injected and extracted from the same well) and "drive through" (the water with reactants is injected to one well and extracted from another one) technologies.

Hydrogen peroxide and sulphuric acid were added to the extracted groundwater and injected back alternately into the two wells thus enhancing the transfer between the soil phases and with this the efficiency of in situ oxidation. The acidic $\mathrm{pH}$ is needed to the iron-catalyzed reaction of hydrogen peroxide [13].

The groundwater levels measured from the surface were 2.07

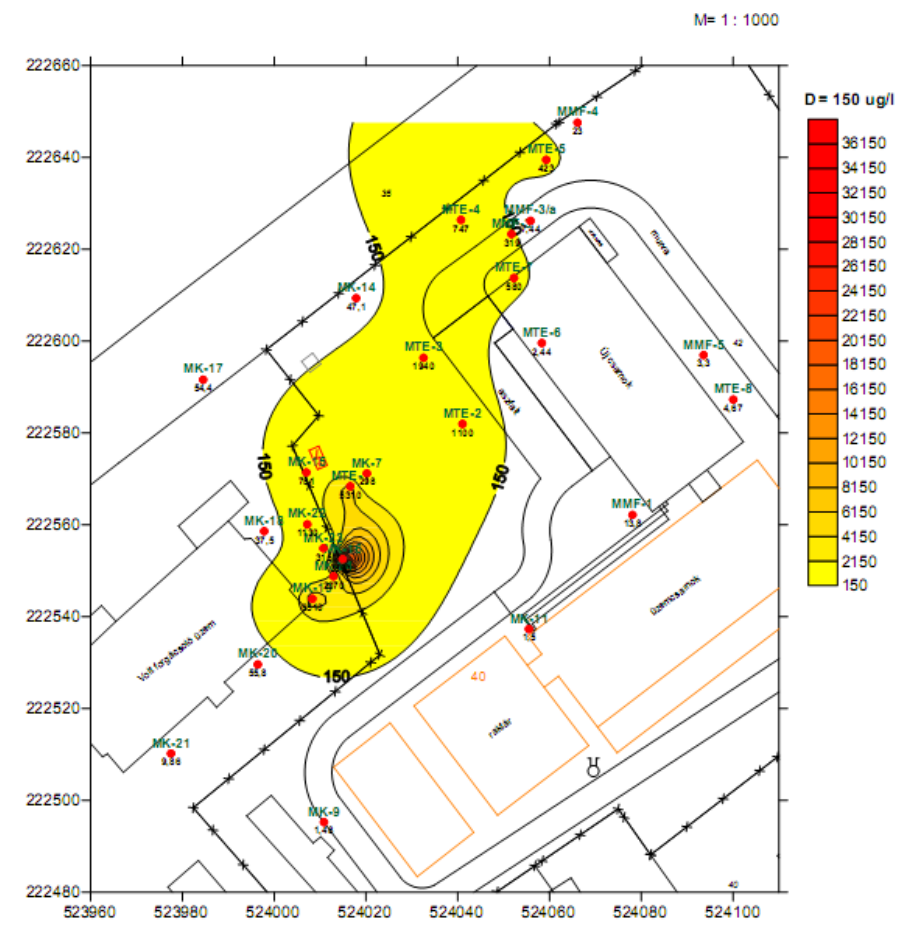

MK, MMF: Groundwater Monitoring Wells, MTE Extraction Wells

Fig. 1. TCE (the main contaminant) distribution in groundwater at the site

and $2.06 \mathrm{~m}$ in wells MTE-1 and M-3, respectively. The volume of the wells was $100 \mathrm{~L}$ and $60 \mathrm{~L}$, respectively. The experiment started with extracting water and sampling from both wells $\left(\mathrm{N}^{\mathrm{o}} 1\right)$. (Sampling $\mathrm{N}^{\circ} 0$ of well MTE-1 was one day before the start of the experiment extracting $180 \mathrm{~L}$ water.). The next $120 \mathrm{~L}$ water was extracted from well M-3, hydrogen peroxide ( $0.7 \mathrm{~L} 30 \%$ solution) was mixed into it, and after adjusting the pH to approx. 3 by sulphuric acid it was injected back. Then this process was repeated at well MTE-1 (Sampling No2): the $180 \mathrm{~L}$ groundwater was pumped out, and mixed with $1 \mathrm{~L}$ hydrogen peroxide solution; the $\mathrm{pH}$ was adjusted to 3 with sulphuric acid and injected back. Again well M-3 was treated in the same way (Sampling $\mathrm{N}^{\circ} 3$ ). After that the oxidant was added at 4 times higher concentration first into the water pumped out from well MTE-1 (Sampling $\mathrm{N}^{\mathrm{o}} 4$ ) then to that from well M-3 (Sampling No5). The water extraction was repeated again in the evening and during the next morning (Sampling $N^{\circ} 6$ and 7) without back-injection.

The concentration of $\mathrm{Cl}^{-}$ions, as well as TCE and $\mathrm{VCH}$ concentration, moreover $\mathrm{pH}$ and electrical conductivity was determined.

\subsection{Integrated methodology for the site assessment} and for technology-monitoring in the laboratory and pilot experiments

Complex methodology including physico-chemical, biological and ecotoxicological methods was used for site assessment and for technology-monitoring. 


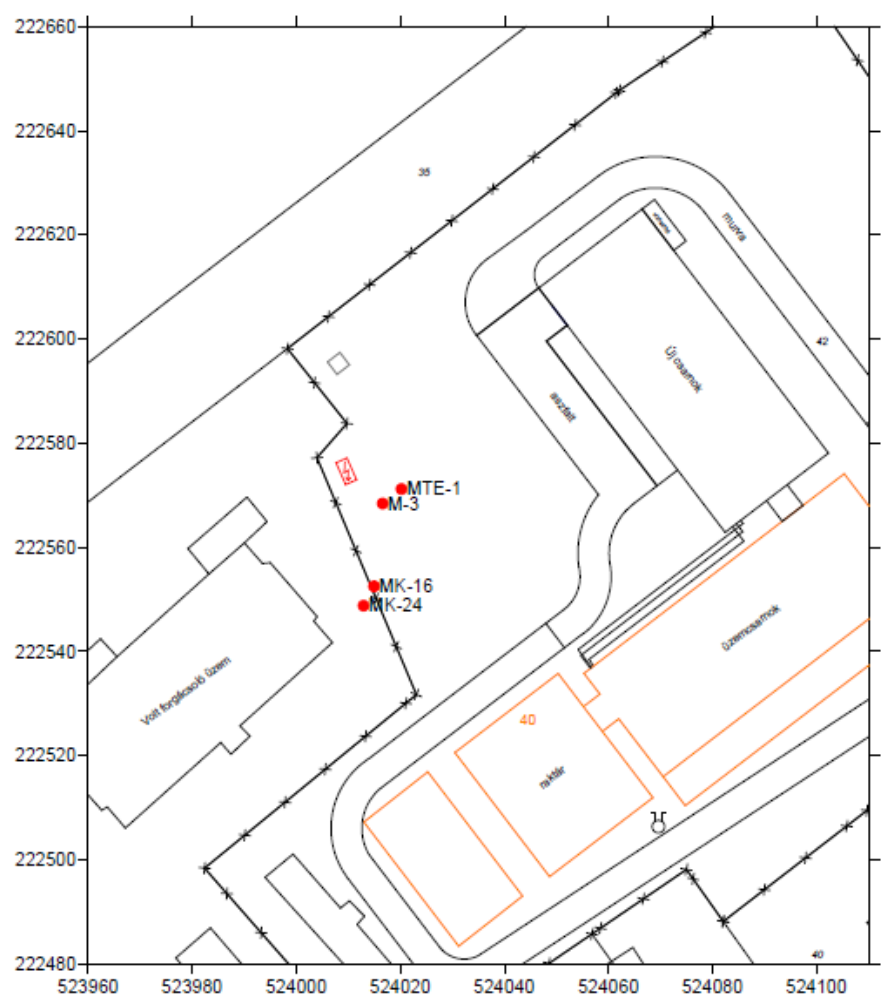

Fig. 2. Location of the wells (MTE-1, M-3) involved in the pilot tests

\subsubsection{Integrated methodology for the site assessment}

VCHs were measured by GC-MS according to Hungarian Standard (MSZ 1484-5:1998).

TCE concentration was determined by gas chromatography before and after treatment. Shimadzu 17A gas chromatograph equipped with Rtx-624 (30m x 0,32mm x 1,8mm) column and FID detector was used with helium as carrier gas and with oven temperature of $60{ }^{\circ} \mathrm{C}$ for $13 \mathrm{~min}$, rising it by $40{ }^{\circ} \mathrm{C} / \mathrm{min}$ to $220^{\circ} \mathrm{C}$. The temperature of injector/detector was $200^{\circ} \mathrm{C} / 220^{\circ} \mathrm{C}$. The split ratio was 10:1. Head space injection was used or liquid injection of samples diluted with ethanol.

Electrical Conductivity and $\mathrm{pH}$ was determined by using WTW Multi 340i/SET.

The biological methods for site assessment to determine the aerobic heterotrophic bacterial cell concentration (Colony Forming Unit-CFU), the Most Probable Number (MPN) of the specialized TCE-degrading cell concentration and the dehydrogenase enzyme activity were applied according to Molnár et al [46. 47].

Aerobic heterotrophic bacterial cell concentration was determined by colony counting after cultivation on Peptone-GlucoseMeat extract (PGM) agar plates in Petri-dishes.

For growing the TCE-degrading cells dilution series of the contaminated soils were used in three replicates, containing TCE as the only carbon source both under aerobic and anaerobic conditions. The applied liquid medium was supplemented with inorganic salt solution, trace elements and with an artificial electron acceptor of the 2-(p-iodophenyl)-3-(p-nitrophenyl)-5phenyl tetrazolium chloride.
Dehydrogenase enzyme activity based on the estimation of 2,3,5-triphenyl-tetrazolium-chloride reduction rate to triphenyl formazan was characterized and used as an index for the overall microbial activity of the soil according to Alef [48].

Two ecotoxicological methods, Vibrio fischeri bioluminescence test and Collembola (Folsomia candida) mortality test were modified and used for toxicity testing in the course of the site assessment [46, 47]. Vibrio fischeri is a marine-living bacterium, but very commonly used for ecotoxicity testing. The Collembolans, commonly known as springtails, are the most numerous and widely occurring insects in terrestrial ecosystems. The endpoints used for the plant and animal tests were $\mathrm{ED}_{20}$ $\left(\mathrm{LD}_{20}\right)$ or $\mathrm{ED}_{50}\left(\mathrm{LD}_{50}\right)$ values, where $\mathrm{ED}_{20}\left(\mathrm{LD}_{20}\right)$ and $\mathrm{ED}_{50}$ $\left(\mathrm{LD}_{50}\right)$ mean soil doses causing $20 \%$ and $50 \%$ inhibition (lethality). $\mathrm{ED}_{20}\left(\mathrm{LD}_{20}\right)$ and $\mathrm{ED}_{50}\left(\mathrm{LD}_{50}\right)$ values were determined from the dose-response curve (inhibition percent values of different dilutions) after sigmoidal fitting using the ORIGIN 8.0 software [46].

\subsubsection{Technology-monitoring applied for bench scale tests} and pilot experiments

The lab-scale technology-monitoring included the gaschromatographic determination of TCE and VCHs concentration, measurement of $\mathrm{pH}$ and conductivity (see above), moreover analysis of inorganic anions such as chloride and sulfate.

The physico-chemical properties and the nutrient status of the soils from the site used in lab-scale tests were analysed $(\mathrm{pH}-$ value, electric conductivity, particle size distribution, humus, nitrogen, phosphorous and organic carbon content).

Capillary electrophoresis was applied for determination of chloride, sulphate and other anions using silica capillary and diamino-propane: tris: benzene-dicarboxylic acid buffer $(\mathrm{pH} 8)$ as background electrolyte. HP 3D CE instrument equipped with silica capillary of $33 \mathrm{~cm}$ at $25{ }^{\circ} \mathrm{C}$ : injection at 50 mbar for $4 \mathrm{sec}$, background electrolite diamino-propane: tris:benzenedicarboxylic acid buffer ( $\mathrm{pH} 8)$.

The oxidant demand of soil (SOD) was also determined by application of sodium persulfate, potassium permanganate and hydrogen peroxide. Laboratory experiments were carried out for quantification of oxidant consumption of 50-50 g of dried soil samples originated from the contaminated site. The experiments were performed in filled in flow-through column reactors, with different oxidant concentrations. The SOD was calculated from the initial and residual oxidant concentrations.

In the case of ISCO using hydrogen peroxide the effect of the oxidant on biological activity of soil microorganisms was also tested. Biological methods such as determination of aerobic/anaerobic heterotrophic bacterial cell concentration (Colony Forming Unit-CFU), the Most Probable Number (MPN) of the specialised TCE-degrading cell concentration and the dehydrogenase enzyme activity were carried out according to Molnár et al [46.47]. 


\section{Results and discussion}

The efficiency of various remediation technologies was studied at lab-scale with soil and groundwater originated from a site highly contaminated with trichloroethylene (TCE).

\subsection{Evaluation of the results of the bench scale tests}

\subsubsection{Cometabolic biodegradation of TCE in the presence} of toluene and cyclodextrin

The biological tests during the site assessment showed that there is a microbial community in the soil and groundwater able to degrade TCE. Cometabolic biodegradation of TCE in groundwater $(\mathrm{GW})$ in the presence of toluene as a growth substrate was studied in batch reactors. The effect of randomly methylated B-cyclodextrin (RAMEB) on biodegradation of TCE was also tested. Initial concentration of TCE in groundwater originated from the site was $2130 \mu \mathrm{g} / \mathrm{L}$. Trichloroethylene was cometabolized by microorganisms in the presence of toluene as a growth substrate. The highest TCE-removal (59.8 $\mathrm{mg}$ TCE) was observed at $1000 \mu \mathrm{g} / \mathrm{mL}$ toluene concentration in the case of groundwater supplied with TCE $(292 \mu \mathrm{g} / \mathrm{mL})$. TCE biodegradation rate increased also with the application of cyclodextrin as shown in the table below (Table 1).

Even though the results were positive, the efficiency of TCEremoval was low and it requires improvement.

\subsubsection{Photodegradation of t TCE by UV illumination in the} presence of cyclodextrin

The UV irradiation in the presence of cyclodextrin was modelled in lab-scale experiment. Cyclodextrin was used as solubilising agent. Complexation of TCE by randomly methylated B-cyclodextrin (RAMEB) gave some protection to TCE against UV decomposition resulting in increased half-life time values at 0, 5, 10 and 20\% RAMEB concentration (Figure 3).

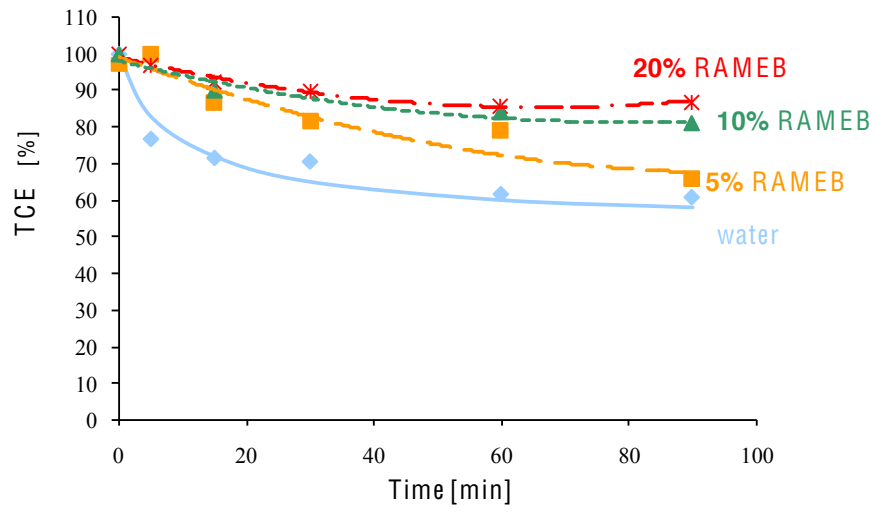

Fig. 3. Decrease of TCE concentration in the solutions at various RAMEB concentrations ( $\diamond 0 \%, \square 5 \%, \triangle 10 \%$ and $* 20 \%$ ) during UV irradiation

To some extent TCE was protected against UV light in the presence of different RAMEB concentrations, but the efficiency of the whole technology (extraction \& UV irradiation together) improved with the increase of RAMEB concentration. Due to the solubility enhancing effect of RAMEB the initial TCE con- centration was increased with the increasing cyclodextrin concentration resulting greater TCE removal (Figure 4).

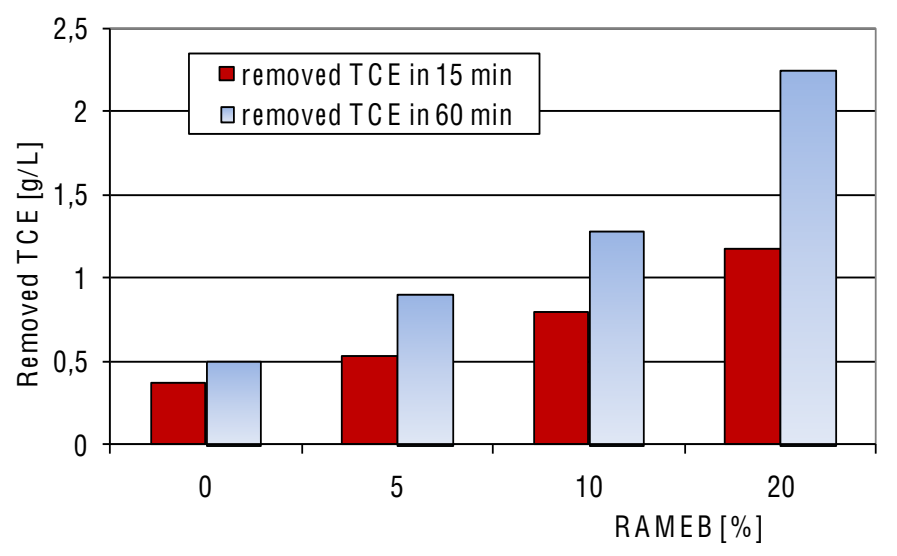

Fig. 4. Efficiency of the UV irradiation technology characterized by the amount of TCE removed during 15 and $60 \mathrm{~min}$ in the modelling experiment

The results clearly show that RAMEB improved the efficiency of extraction \& UV irradiation under the applied experimental conditions. Inclusion complexes protected TCE against UV decomposition resulting in increased half-life time values.

\subsubsection{In situ chemical oxidation for treatment of contami- nated groundwater and soil with trichloroethylene}

In situ chemical oxidation of contaminated groundwater applying different oxidants such as sodium persulfate, potassium permanganate and hydrogen peroxide was modelled in lab-scale batch reactors. Figures 57 show the efficacy of different oxidants and additives on TCE-removal from groundwater.

These results show that the use of ferrous ion in conjunction with persulfate treatment may achieve a synergistic effect on TCE removal. The use of ferrous ion in conjunction with persulfate treatment may produce a synergistic effect on TCE removal enhancing the removal from $47 \%$ to about $69 \%$ and from $60 \%$ to about $80 \%$ applying 18 and $36 \mathrm{~g} / \mathrm{L}$ sodium persulfate concentration, respectively (Figure 5). In the case of ISCO with persulfate application ferrous ion could activate the persulfate anion to produce a powerful oxidant known as the sulfate radical. While no significant enhancement was achieved by double iron concentration further improvement was observed by adding also $\mathrm{Na}_{2} \mathrm{~S}_{2} \mathrm{O}_{3}$ to the solutions. Addition of sodium thiosulfate $\left(\mathrm{Na}_{2} \mathrm{~S}_{2} \mathrm{O}_{3}\right)$ as reducing agent to the persulfate can form a persulfate-thiosulfate redox system. This could be necessary because the rapid conversion of all $\mathrm{Fe}^{2+}$ to $\mathrm{Fe}^{3+}$ may limit the ultimate oxidizing capability of the system The thiosulfate enhanced the availability of ferrous ion for persulfate activation. RAMEB addition was beneficial at low persulfate levels.

Potassium permanganate was more effective than persulfate treatment (Figure6). The applied $0.6 \mathrm{~g} / \mathrm{L} \mathrm{KMnO}_{4}$ was able to completely degrade $100 \mathrm{mg} / \mathrm{L}$ and also $1000 \mathrm{mg} / \mathrm{L} \mathrm{TCE}$ in groundwater after 24 hours. But the high amount of $\mathrm{MnO}_{2}$ was precipitated in the reactors $(0.35$ and $0.94 \mathrm{~g} / 250 \mathrm{~mL}$ in the reac- 
Tab. 1. Cometabolic biodegradation of TCE in the presence of toluene and RAMEB

\begin{tabular}{|c|c|c|c|}
\hline \multirow{2}{*}{ Reactors } & \multirow{2}{*}{$\begin{array}{l}\text { Anaerobic TCE-degrading cell } \\
\text { concentration [cell/mL] }{ }^{*} 10^{2}\end{array}$} & \multicolumn{2}{|c|}{ TCE-degradation } \\
\hline & & [\%] & [mg] \\
\hline GW (without additives) & 15 & 10 & 0.5 \\
\hline $\mathrm{GW}+500 \mu \mathrm{g} / \mathrm{mL}$ toluene & 110 & 48 & 2.5 \\
\hline $\mathrm{GW}+292 \mu \mathrm{g} / \mathrm{mL}$ TCE & 46 & 14 & 20.4 \\
\hline $\mathrm{GW}+292 \mu \mathrm{g} / \mathrm{mL}$ TCE $+0,5 \% \mathrm{CD}$ & 460 & 30 & 43.8 \\
\hline $\mathrm{GW}+292 \mu \mathrm{g} / \mathrm{mL}$ TCE $+1,0 \% \mathrm{CD}$ & 1100 & 30 & 43.8 \\
\hline $\mathrm{GW}+292 \mu \mathrm{g} / \mathrm{mL}$ TCE $+500 \mu \mathrm{g} / \mathrm{mL}$ toluene & 210 & 32 & 46.7 \\
\hline $\mathrm{GW}+292 \mu \mathrm{g} / \mathrm{mL}$ TCE $+1000 \mu \mathrm{g} / \mathrm{mL}$ toluene & 1100 & 41 & 59.8 \\
\hline
\end{tabular}

tors with $1000 \mathrm{mg} / \mathrm{L}$ TCE using 1.2 and $6.0 \mathrm{~g} / \mathrm{L}$ potassium permanganate). Therefore the disadvantage of using $\mathrm{KMnO}_{4}$ is that the insoluble precipitate can significantly reduce soil permeability on site and can easily cause clogging in the wells. The same situation may appear if any strong oxidants are applied together with different ferrous salts. A possible disadvantage of using ferrous salts with strong oxidation agents can be the clogging in the soil because the poorly water soluble ferric-oxyhydroxides hinder the subsurface water flow.

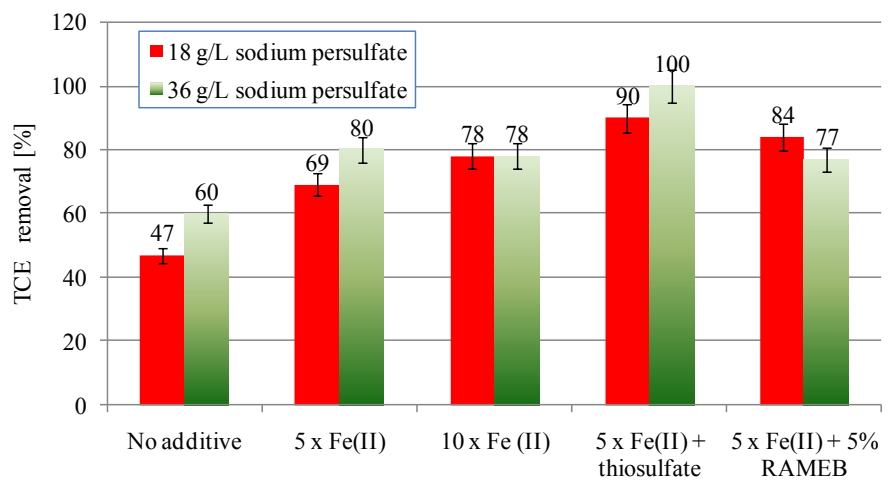

Application of sodium persulfate of 18 and $36 \mathrm{~g} / \mathrm{L}$ concentration (red and green, respectively) with and without various additives: 5 and 10 times molar excess to TCE of ferrous sulfate, 5 times molar excess to TCE of sodium thiosulfate

Fig. 5. Efficacy of persulfate treatment on groundwater contaminated by $100 \mathrm{mg} / \mathrm{L} \mathrm{TCE}$

After hydrogen peroxide oxidation (Figure 7 the high TCE concentration $(1 \mathrm{~g} / \mathrm{l})$ in the groundwater dropped significantly after 24 hours. Inactivated $\mathrm{H}_{2} \mathrm{O}_{2}$ showed slight reduction (53$56 \%$ ) of TCE concentrations. But iron activation with the addition of $\mathrm{FeSO}_{4}(11 \mathrm{~g} / \mathrm{l})$ presented an increased rate of TCE degradation (99-100\%) after one day. Applying RAMEB additive somewhat lower removal $(92 \%)$ was observed.

Peroxide based ISCO with $\mathrm{FeSO}_{4}$ was more effective than sodium persulfate treatment.

The cost of the oxidant chemicals and the soil oxidant demand (SOD) driving the required oxidants are some important factors besides others in the selection of the remediation technology.

The measured SOD for peroxide was relatively low which makes $\mathrm{H}_{2} \mathrm{O}_{2}$ a suitable oxidant for the site. The average soil

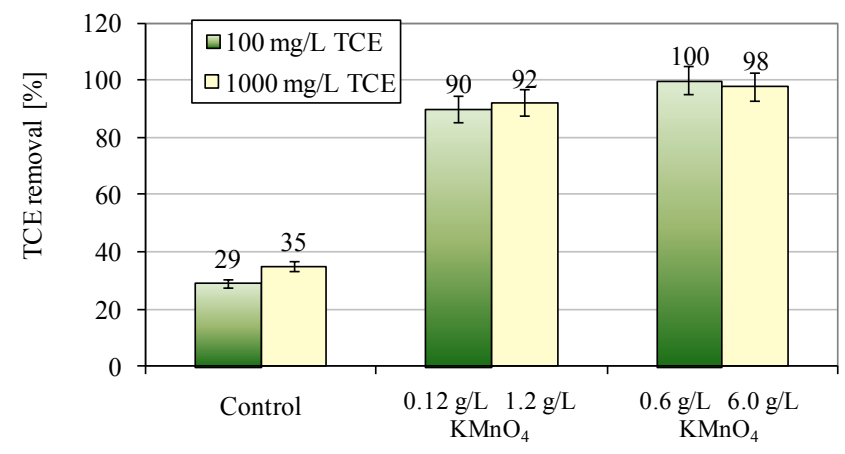

Fig. 6. TCE removal from groundwater of 100 and $1000 \mathrm{mg} / \mathrm{L}$ initial TCE Concentration (green and pale yellow, respectively) by potassium permanganate of 6.6 and 33 fold molar excess $(0.12 / 1.2 \mathrm{~g} / \mathrm{L}$ and $0.6 / 6.0 \mathrm{~g} / \mathrm{L}$ concentration, respectively) after $24 \mathrm{~h}$

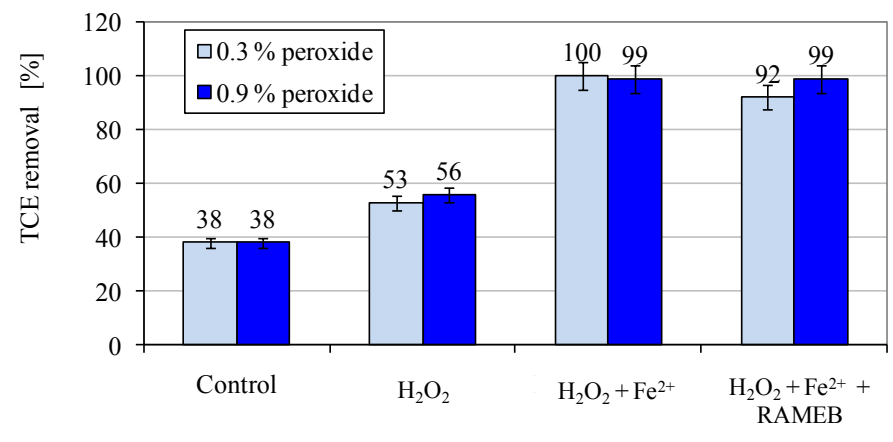

Fig. 7. Efficacy of peroxide treatment on groundwater contaminated by $1000 \mathrm{mg} / \mathrm{L}$ TCE Lab-Scale Experiments by Hydrogen Peroxide of 3.0 and $9.0 \mathrm{~g} / \mathrm{L}$ Concentration (pale and dark blue, respectively) after $24 \mathrm{~h}$

oxidant demand was $1.2 \mathrm{~g} / \mathrm{kg}$ in the case of $\mathrm{H}_{2} \mathrm{O}_{2}$ application and a $1.8 \mathrm{~g} / \mathrm{kg}$ using sodium persulfate.

Based on these results hydrogen peroxide was selected for further model experiments to be performed on the soil originated from the site (permanganate was not selected because of the large amount of precipitate, persulfate falls out because of the high sulfate burden to the soil). $\mathrm{H}_{2} \mathrm{O}_{2}$ is attractive as in situ oxidant because of its relatively powerful oxidation potential with ferrous iron, its ability to oxidize a variety of organic chemicals and its relatively low chemical cost. But the evaluation of the impact of peroxide on the native microbial population is also very important. 
Tab. 2. In situ chemical oxidation with $\mathrm{H}_{2} \mathrm{O}_{2}$ of the TCE-contaminated saturated soil and groundwater: effect of $\mathrm{H}_{2} \mathrm{O}_{2}$ on the soil microbes and TCE

\begin{tabular}{|c|c|c|c|c|}
\hline Reactors & $\begin{array}{r}\text { Anaerobic heterotrophic } \\
\text { cell conc. (CFU) } \\
{\left[\text { cell* } 10^{5} / \mathrm{g} \text { soil] }\right.}\end{array}$ & $\begin{array}{r}\text { Dehydrogenase enzyme } \\
\text { activity } \\
{[\mu \mathrm{g} T P F / g \text { soil }]}\end{array}$ & $\begin{array}{r}\text { AnaerobicTCE degrading } \\
\text { cell conc. (MPN) } \\
{\left[\text { cell* } 10^{5} / \mathrm{g} \text { soil] }\right.}\end{array}$ & $\begin{array}{r}\text { TCE concentration } \\
\text { in the reactors } \\
{[\mu \mathrm{g} / \mathrm{L}]}\end{array}$ \\
\hline Control & 23.7 & 5.41 & 1.5 & - \\
\hline+ TCE & 28.6 & 7.74 & 150 & 14700 \\
\hline$+1.0 \% \mathrm{H}_{2} \mathrm{O}_{2}$ & 43.5 & 4.10 & 24 & - \\
\hline$+\mathrm{TCE}+0.5 \% \mathrm{H}_{2} \mathrm{O}_{2}$ & 29.6 & 1.59 & 460 & 8420 \\
\hline$+\mathrm{TCE}+1.0 \% \mathrm{H}_{2} \mathrm{O}_{2}$ & 48.1 & 5.22 & 110 & 3840 \\
\hline$+\mathrm{TCE}+2.0 \% \mathrm{H}_{2} \mathrm{O}_{2}$ & 30.1 & 3.08 & 210 & 2540 \\
\hline
\end{tabular}

Tab. 3. Comparative evaluation of the technologies performed at bench-scale experiments

\begin{tabular}{|c|c|c|c|c|c|c|}
\hline & \multirow{2}{*}{ Pump\&Treat } & \multirow{2}{*}{ UV } & \multirow{2}{*}{ Bioremediation } & \multicolumn{3}{|c|}{ ISCO } \\
\hline & & & & $\mathrm{KMnO}_{4}$ & $\mathrm{Na}_{2} \mathrm{~S}_{2} \mathrm{O}_{8}$ & $\mathrm{H}_{2} \mathrm{O}_{2}$ \\
\hline Effectiveness & low & medium & low & high & medium & high \\
\hline Duration of remediation & long & medium & long & short & short & short \\
\hline Further investment costs at the site & no & high & no & no & no & no \\
\hline Maintenance costs (chemicals, labor and energy) & medium & high & low & medium/ high & medium/ high & medium \\
\hline Regulatory compliance & low & high & high & high & high & high \\
\hline Need of follow-up technologies & high & low & low & low/medium & low & low \\
\hline
\end{tabular}

ISCO with hydrogen peroxide of the saturated soil in a static reactor was performed while the microbial activity in the saturated soils was also investigated. Compared to the control supplied with TCE, no significant changes were observed in the anaerobic cell concentrations and enzyme activities.

The first results of the microbiological investigations (Table 2 showed that peroxide treatment did not decrease biological activity in soil and it could be a viable strategy to treat the TCE contaminated site.

The effect of $\mathrm{H}_{2} \mathrm{O}_{2}$ treatment on the aerobic microflora of the three-phase soil was also studied. In this case our results (not shown here) indicated that although aerobic microbial communities were slightly negatively affected after multiple doses of $2 \% \mathrm{H}_{2} \mathrm{O}_{2}$ on the short term, the microbial biomass recovered and microbial activity started after 3 weeks. Aerobic heterotrophic cell concentration decreased by about $40 \%$ in the first 2 weeks after repeated hydrogen peroxide treatment, but the microbial population remained viable. Addition of $\mathrm{H}_{2} \mathrm{O}_{2}$ at low concentrations $(0.5 \%)$ stimulated the activity of aerobic soil microflora.

\subsubsection{Summary of the bench-scale experiments}

These results of laboratory-scale testing may not be directly applied to the design of a corresponding field-scale study however these results provide the necessary information for a pilotscale design.

Results of the comparative evaluation of the technologies performed at bench-scale experiments (Table 3 show the main advantages of in situ chemical oxidation (ISCO) applying hydro- gen peroxide: high effectiveness, short time requirement and medium maintenance costs. The in situ chemical oxidation technology has the potential to be an effective means of removing TCE and VCHs at rates much more rapid than bioremediation and P\&T strategies.

On the basis of these considerations and the results of the labscale experiments ISCO using $\mathrm{H}_{2} \mathrm{O}_{2}$ was selected for pilot tests on the contaminated site.

\subsection{Pilot tests on the contaminated site}

\subsubsection{Summary of the site assessment}

26 monitoring wells were established and the extent of contamination was determined. High VOCs concentrations (300$40,000 \mu \mathrm{g} / \mathrm{L})$ and especially high TCE (150-35,000 $\mu \mathrm{g} / \mathrm{L})$ concentrations were observed in the groundwater. The depth of groundwater was $2.5 \mathrm{~m}$ at the time of the assessment. The geotechnical assessment showed the vertical soil profile including: mixed soil backfill overlaying the sand and the sand with gravel layers. Under this layer silt, sandy and clayey silt was found.

The soil microbial activity was characterized by the aerobic heterotrophic cell concentration (CFU) and by the aerobic and anaerobic TCE-degrading cell concentration (Table 4). The latter was found high enough to assume that there is a microbial consortium able to degrade TCE; therefore the bioremediation as a technology alternative was also taken into consideration.

The ecotoxicity methods (Table 5]) showed that even the upper layer but especially the deeper layers of the soil pose a risk to the environment and humans. 
Tab. 4. Assessment of the soil microflora

\begin{tabular}{lrrr}
\hline & $\begin{array}{r}\text { CFU } \\
{\left[\text { cell/g or cell/mL] }{ }^{*} 10^{5}\right.}\end{array}$ & $\begin{array}{r}\text { Aerobic TCE-degrading } \\
\text { cell concentration } \\
\text { [cell/g or cell/mL] }\end{array}$ & $\begin{array}{r}\text { Anaerobic TCE-degrading } \\
\text { cell concentration } \\
{[\text { cell/g or cell/mL] }}\end{array}$ \\
\hline Soil A $(1.5-2.5 \mathrm{~m})$ & 90.0 & $<3$ & 1100 \\
Soil B $(2.0-3.5 \mathrm{~m})$ & 34.5 & $<3$ & 1500 \\
Soil C $(3.5-5.0 \mathrm{~m})$ & 28.5 & $<3$ & 150 \\
Soil D $(3.5-6.0 \mathrm{~m})$ & 26.0 & $<3$ & 240 \\
Groundwater $\mathrm{A}^{*}$ & 0.1 & $<3$ & $<3$ \\
Groundwater $\mathrm{B}^{*}$ & 0.05 & $<3$ & $<3$ \\
\hline
\end{tabular}

${ }^{*}$ Groundwater A - from monitoring well, Groundwater B -from extraction well

Tab. 5. Toxicity of soil samples from different depth expressed in $\mathrm{ED}_{20}$ and $\mathrm{ED}_{50}$ values of Folsomia candida acute mortality test

\begin{tabular}{lrrr}
\hline Sample & ED $_{\mathbf{2 0}}$ [g soil] & ED $_{\mathbf{5 0}}$ [g soil] & Toxicity \\
\hline Soil A & 10.9 & 18.0 & slightly toxic \\
Soil B & $>20.0$ & $>20.0$ & non toxic \\
Soil C & 12.9 & $>20.0$ & non-toxic \\
Soil D & 5.5 & 11.3 & toxic \\
\hline
\end{tabular}

\subsubsection{Pilot demonstration of hydrogen peroxide oxidation} combined with alternate pumping on the site

On the basis of the results provided by the lab-scale tests and site assessment the ISCO method using hydrogen peroxide by alternate pumping was demonstrated in pilot field tests. The concentration of $\mathrm{Cl}^{-}$ions, as well as TCE and VCHs concentration, moreover $\mathrm{pH}$ and electrical conductivity was determined.

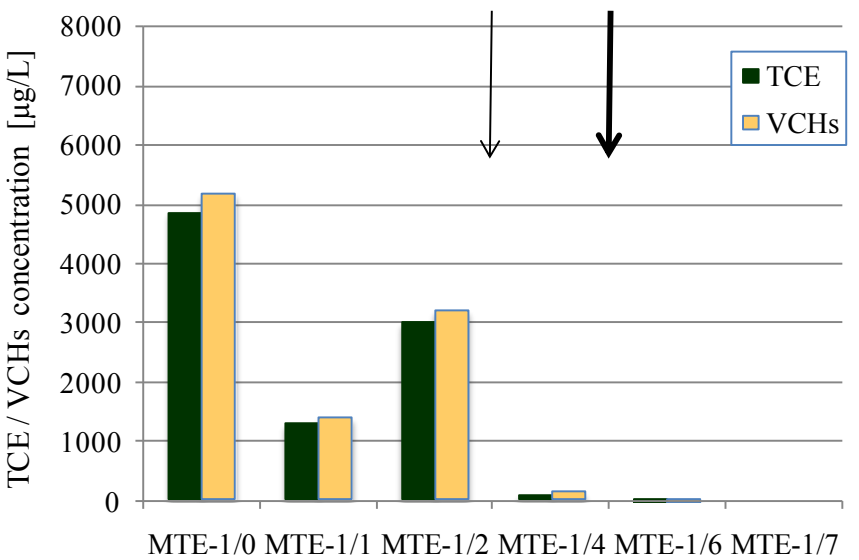

Fig. 8. Concentration of TCE (dark green) and VCHs (pale orange) in MTE-1 Well. The arrows show the addition of hydrogen peroxide (the thicker line shows the addition of 4-times higher amount of oxidant)

The $\mathrm{pH}$ of the extracted groundwater remained unchanged due to the buffering capacity of the soil. The electric conductivity changed in parallel with the gradually increasing sulfate concentration (starting from $440 \mathrm{mg} / \mathrm{L}$ and $420 \mathrm{mg} / \mathrm{L}$ and reaching $2700 \mathrm{mg} / \mathrm{L}$ and $3000 \mathrm{mg} / \mathrm{L} \mathrm{SO}_{4}^{2-}$ in wells MTE-1 and M-3, respectively) due to the sulfuric acid additions. The increase in chloride concentration (starting from $15.1 \mathrm{mg} / \mathrm{L}$ and $20.7 \mathrm{mg} / \mathrm{L}$ and reaching $24.2 \mathrm{mg} / \mathrm{L}$ and $27.7 \mathrm{mg} / \mathrm{L} \mathrm{Cl}^{-}$in wells MTE-1

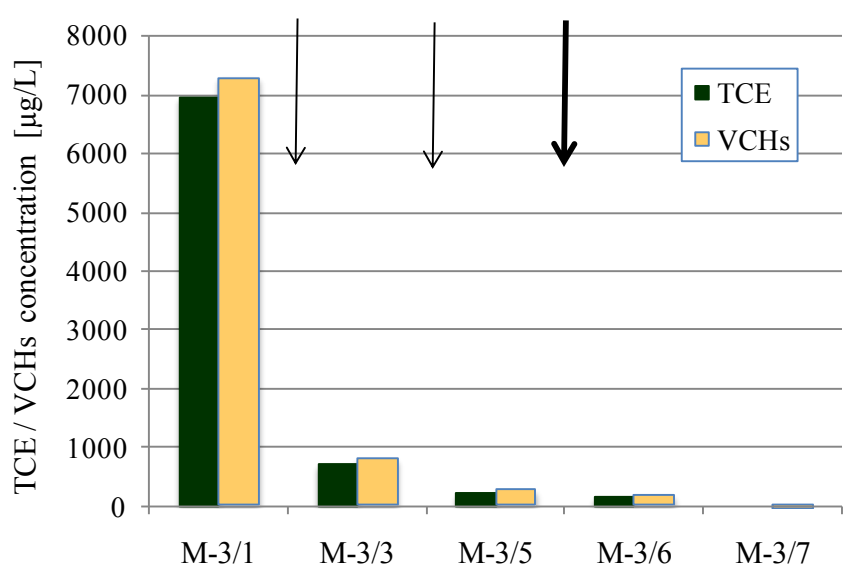

Fig. 9. Concentration of TCE (dark green) and VCHs (pale orange) in M-3 well. The arrows show the addition of hydrogen peroxide (the thicker line shows the addition of 4-times higher amount of oxidant)

and M-3, respectively) is the consequence of the oxidation of the contaminant (Figure 8 97). The TCE concentration started to decrease after pumping in well MTE-1 (from sampling 0 to sampling 1) and it was practically diminished after addition of the oxidant (Figure 8). The concentration of perchloroethylene and VCHs decreased in parallel. In the samples MTE-1/4-7 and M-3/6-7 the TCE concentration was below the remediation goal (0.15 mg/L).

The in situ chemical oxidation with alternating in-well treatments proved to be very efficient: the pollutants practically disappeared after one day.

It was interesting to observe that the treatment was more successful in well MTE-1 although only 2 additions of oxidant were applied in this well. This shows that the two wells are not independent: treating M-3 results in lower pollutant concentration in well MTE-1, too, as M-3 is in up-stream position. Therefore the pollutant arrives from the source from the direction of M-3. On the other hand well MTE-1 providing higher volume of water is probably more permeable for hydrogen peroxide which ensures better and longer lasting effect.

\section{Conclusion}

The aim of our study was to evaluate the applicability and efficiency of different technologies for treatment of TCE con- 
taminated groundwater and soil. Feasibility of bioremediation based on enhanced biodegradation, pump \& treat by UV irradiation and in situ chemical oxidation (ISCO) applying different oxidants (sodium persulfate, potassium permanganate and hydrogen peroxide) was studied in lab-scale experiments.

According to the performed laboratory scale experiments of the technologies TCE-concentration of the contaminated water and soil was significantly reduced in all cases.

In the case of biodegradation experiments trichloroethylene was cometabolized by microorganisms in the presence of toluene as a growth substrate. Even though positive results were demonstrated here (40-50\% TCE-degradation in 10 days), the efficiency of the TCE-removal was low.

In the case of UV irradiation modelled in lab-scale complexation of TCE by RAMEB resulted increased half-life time values thanks to the protection against UV decomposition. However the efficiency of the extraction \& UV irradiation technology was improved with the increase of RAMEB concentration under the applied experimental conditions.

The significant advantages of the chemical oxidation technologies were their speed and efficacy of contaminant destruction compared to biological processes and UV decomposition.

In the case of in situ chemical oxidation the use of ferrous ion in conjunction with persulfate treatment enhanced the removal from $47 \%$ to about $69 \%$ and from $60 \%$ to about $80 \%$ at 18 and $36 \mathrm{~g} / \mathrm{L}$ sodium persulfate concentration, respectively.

The laboratory experiments showed, that potassium permanganate was more effective than persulfate treatment. The applied $0.6 \mathrm{~g} / \mathrm{L} \mathrm{KMnO}_{4}$ was able to completely degrade $100 \mathrm{mg} / \mathrm{L}$ and also $1000 \mathrm{mg} / \mathrm{L}$ TCE in groundwater after 24 hours. But in the case of ISCO with permanganate precipitate $\left(\mathrm{MnO}_{2}\right)$ was formed which can easily cause clogging in the wells in the case of field application.

The comparison of different technologies performed in the lab revealed that ISCO with $\mathrm{H}_{2} \mathrm{O}_{2}$ in the presence of iron was the most effective. The applied $0.3 \% \mathrm{H}_{2} \mathrm{O}_{2}$ was able to completely degrade $1000 \mathrm{mg} / \mathrm{L}$ TCE in groundwater after 24 hours at acidic pH. $\mathrm{H}_{2} \mathrm{O}_{2}$ is attractive as in situ oxidant because of its relatively powerful oxidation potential with iron and due to its relatively low cost. Soil oxidant demand was also relatively low $(1.2 \mathrm{~g} / \mathrm{kg})$ in the case of peroxide application.

While further laboratory experiments and field assessments are required, it is clear that hydrogen peroxide application to three-phase or saturated soil does not sterilize the soil microbial populations. Moreover enhanced activity of aerobic soil microflora was observed further to addition of $\mathrm{H}_{2} \mathrm{O}_{2}$ at low concentration $(0.5 \%)$. The $\mathrm{O}_{2}$ released during hydrogen peroxide oxidation can enhance natural attenuation.

The results of the pilot tests on the contaminated site confirmed the laboratory findings: ISCO using hydrogen peroxide was very efficient. The pollutants (TCE and VCHs) practically disappeared after two days of application. On the basis of the results provided by lab-scale experiments and pilot tests ISCO using hydrogen-peroxide can be a feasible and cost-effective in situ method for achieving risk-based remediation goals at this site.

\section{List of acronyms}

CFU Colony Forming Unit

CHP Catalyzed Hydrogen Peroxide

GW Groundwater

ISB In situ Biological Oxidation

ISCO In situ Chemical Oxidation

$P C E$ Tetrachloroethylene

$P \mathcal{E} T$ Pump and Treat

$R A M E B$ Random methylated beta-cyclodextrin

$S O D$ Oxidant demand of soil

TCE Trichloroethylene

$\mathrm{VCH}$ Volatile chlorinated hydrocarbon

VOC Volatile organic compound

\section{References}

1 Schnarr MJ, Farquhar GJ, An in situ oxidation technique to destroy residual DNAPL from soil, In: Third International Conference on Ground Water Quality; Dallas, TX, 1992.

2 Vella PA, Veronda B, Oxidation of trichloroethylene: A comparison of potassium permanganate and Fenton's reagent, In: Third International Symposium on Chemical Oxidation, Technology for the Nineties; Vanderbilt University, Nashville, TN, 1992.

3 Siegrist RL, Gates DD, West OR, Donaldson TL, Liang L, Webb OF, In situ physical/chemical treatment technologies for remediation of contaminated sites: Applicability, development status, and research needs, Department of Energy; 4238 Washington DC, US, 1994.

4 Stokley KE, Drake EN, Prince RC, The role of Fenton's reagent in soil bioremediation, In: Fourth International In Situ and On-Site Bioremediation Symposium; New Orleans, LA, 1997.

5 Schnarr M, Truax C, Hood E, Gonully T, Stickney B, Laboratory and controlled field experimentation using potassium permanganate to remediate trichloroethylene and perchloroethylene DNAPLs in porous media, Journal of Contaminant Hydrology, 29, (1998), 205-224.

6 Sahl JW, Munakata-Marr J, The Effects of In situ Chemical Oxidation on Microbiological Processes: A Review, Remediation Journal, 16(3), (2006), 57-70.

7 Sunder M, Hempel DC, Oxidation of tri- and perchloroethene in aqueous solution with ozone and hydrogene peroxide in a tube reactor, Water $\mathrm{Re}$ search, 31(1), (1997), 33-40.

8 Anotai J, Su CC, Tsa YC, Lu MC, Effect of hydrogen peroxide on aniline oxidation by electro-Fenton and fluidized-bed Fenton processes, Journal of Hazardous Materials, 183, (2010), 888-893.

9 Masomboon N, Ratanatamskul C, Lu M C, Chemical oxidation of 2,6dimethylaniline by electrochemically generated Fenton's reagent, Journal of Hazardous Materials, 176, (2010), 92-98.

10 Huling SG, Pivetz BE, In-Situ Chemical Oxidation, United States Environmental Protection Agency, 2006. Index I. PURPOSE II.

11 Kang N, Hua I, Suresh P, Rao C, Enhanced Fenton_s destruction of nonaqueous phase perchloroethylene in soil systems, Chemosphere, 63, (2006), 1685-169.

12 ITRC (Interstate Technology \& Regulatory Council), Technical and Regulatory Guidance for In Situ Chemical Oxidation of Contaminated Soil and Groundwater, 2nd ISCO-2., Interstate Technology \& Regulatory Council, In Situ Chemical Oxidation Team; Washington D.C., 2005, http://www. itrcweb.org/Guidance/GetDocument?documentID=45 
13 Chen G, Hoag GE, Chedda P, Nadim F, Woody BA, Dobbs GM, The mechanism and applicability of in situ oxidation of trichloroethylene with Fenton's reagent, Journal of Hazardous Materials, 87, (2001), 171-186.

14 Jung J, Yoon JH, Chung $\mathbf{H H}$, Lee MJ, Comparative study of $\mathrm{H}_{2} \mathrm{O}_{2}$ and $\mathrm{O}_{3}$ effects on radiation treatment of TCE and PCE, Chemosphere, 51, (2003), 881-885.

15 Weeks KR, Bruell CJ, Mohanty NR, Use of Fenton's reagent for the degradation of TCE in aqueous system and soil slurries, Soil and Sediment Contamination, 9(4), (2000), 331-345.

16 Liang C, Bruell CJ, Marley MC, Sperry KL, Thermally activated persulfate oxidation of trichloroethylene (TCE) and 1,1,1-trichloroethane (TCA) in aqueous and soil slurry systems, Soil and Sediment Contamination, 12(2), (2003), 207-228.

17 Liang C, Bruell CJ, Marley MC, Sperry KL, Persulfate oxidation for in situ remediation of TCE. I. Activated by ferrous ion with and without a persulfatethiosulfate redox couple, Chemosphere, 55(9), (2004), 213-223.

18 Liang C, Huang CF, Mohanty N, Lu CJ, Kurakalva RM, Hydroxypropylbeta-cyclodextrin-mediated iron-activated persulfate oxidation of trichloroethylene and tetrachloroethylene, Industrial and Engineering Chemistry Research, 46, (2007), 6466-6479.

19 Liang C, Lee IL, In situ iron activated persulfate oxidative fluid sparging treatment of TCE contamination-A proof of concept study, Journal of Contaminant Hydrology, 100, (2008), 6466-6479.

20 Liang C, Lee I L, Hsu I Y, Liang C P, Lin Y L, Persulfate oxidation of trichloroethylene with and without iron activation in porous media, Chemosphere, 70, (2008), 426-435.

21 Luu PP, Yung CW, Sun AK, Wood TK, Monitoring trichloroethylene mineralization by Pseudomonas cepacia G4 PR1, Applied Microbiology and Biotechnology, 44, (1995), 259-264.

22 Richardson RE, Bhupathiraju V, Song D, Goulet T, Alvarez-Cohen $\mathbf{L}$, Phylogenetic characterization of microbial communities that reductively dechlorinate TCE based upon a combination of molecular techniques, Environmental Science and Technology, 36, (2002), 2652-2662.

23 Miller CM, Valentine RL, Roehl ME, Alvarez P, Chemical and microbiological assessment of pendimethalin-contaminated soil after treatment with Fenton's reagent, Water Research, 30, (1996), 2579-2586.

24 Büyüksönmez F, Hess TF, Crawford RL, Paszczynski A, Watts RJ, Optimization of simultaneous chemical and biological mineralization of perchloroethylene, Applied and Environmental Microbiology, 65, (1999), 27842788.

25 Allen SA, Reardon KF, Remediaton of contaminated soils by combined chemical and biological treatments, In: Wickamanayake GB, Gavaskar AR (eds.), Remediation of chlorinated and recalcitrant compounds, Battelle Press; Columbus, OH, 2000, pp. 301-306.

26 Kastner JR, Domingo JS, Denham M, Molina M, Brigmon R, ffect of chemical oxidation on subsurface microbiology and trichloroethene biodegradation, Bioremediation Journal, 4(3), (2000), 212-236.

27 Droste EX, Marley MC, Parikh JM, Lee AM, Observed enhanced reductive dechlorination after in situ chemical oxidation pilot test, In: Third International Conference on Remediation of Chlorinated and Recalcitrant Compounds; Monterey, CA, 2002.

28 Azadpour-Keeley A, Wood LA, Parikh JM, Lee TR, Mravik SC, Microbial responses to in situ chemical oxidation, six-phase heating, and steam injection remediation technologies in groundwater, Remediation, 14(4), (2004), 5-17.

29 Macbeth TW, Peterson LN, Starr RC, Sorenson KS, Goehlert R, Moor $\mathrm{KS}$, ISCO impacts on indigenous microbes in a PCE-DNAPL contaminated aquifer, In: Eighth International In Situ and On-Site Bioremediation Symposium; Baltimore, MD, 2005.

30 Hazen TC, Sewell G, Gavaskar AR, The effect of source remediation methods on the presence and activity of indigenous subsurface bacteria at launch complex 34, In: Evaluation work plan; Battelle, Cape Canaveral Air Station, Florida, Columbus, OH, 2000.

31 Klens J, Scarborough S, Graves D, The effects of permanganate oxidation on subsurface microbial populations, In: Lesson A, Kelley ME, Rifai HS, Magar VS (eds.), Natural attenuation of environmental contaminants, Vol. 6, Battelle Press; Columbus, OH, 2001, pp. 253-259.

32 Hrapovic L, Sleep BE, Major DJ, Hood E, Laboratory study of treatment of trichloroethene by chemical oxidation followed by bioremediation, Environmental Science and Technology, 39, (2005), 2888-2897.

33 Martens DA, Frankenberger WT, Enhanced degradation of polycyclic aromatic hydrocarbons in soil treated with an advanced oxidative processFenton's reagent, Journal of Soil Contamination, 4(2), (1995), 175-190.

34 Martens DA, Frankenberger WT, Enhanced degradation of polyvinyl alcohol by Pycnoporus cinnabarinus after pretreatment with Fenton's reagent, Applied and Environmental Microbiology, 65, (1999), 1798-1800.

35 Kao CM, Wu MJ, Enhanced TCDD degradation by Fenton's reagent preoxidation, Journal of Hazardous Materials, 74, (2000), 197-211.

36 Nam K, Kukor JJ, Combined ozonation and biodegradation for remediation of mixtures of polycyclic aromatic hydrocarbons in soil, Biodegradation, 11(1), (2000), 1-9.

37 Zeng Y, Hong PK, Wavrek D, Integrated chemical-biological treatment of benzo[a]pyrene, Environmental Science and Technology, 34, (2000), 854 862.

38 Nam K, Rodriguez W, Kukor JJ, Enhanced degradation of polycylic aromatic hydrocarbons by biodegradation combined with a modified Fenton reaction, Chemosphere, 45, (2001), 11-20.

39 Lee BD, Hosomi M, EA hybrid Fenton oxidation-microbial treatment for soil highly contaminated with benz(a)anthracene, Chemosphere, 43, (2001), 1127-1132.

40 Nadarajah N, Van Hamme J, Pannu J, Singh J, Ward O, Enhanced transformation of polycyclic aromatic hydrocarbons using a combined Fenton's reagent, microbial treatment and surfactants, Applied Microbiology and Biotechnology, 59, (2002), 540-544.

41 Piskonen R, Itavaara M, Evaluation of chemical pretreatment of contaminated soil for improved PAH bioremediation, Applied Microbiology and Biotechnology, 65, (2004), 627-634.

42 Blanford WJ, Barackman M, Boving TB, Klingel E, Brusseau M, Cyclodextrin-enhanced vertical flushing of a trichloroethene contaminated aquifer, Ground Water Monitoring and Remediation, (2000), 58-66.

43 Boving TB, Brusseau ML, Solubilization and removal of residual trichloroethene from porous media: comparison of several solubilization agents, Journal of Contamination Hydrology, 42, (2000), 51-67.

44 Tick GR, Lourenso F, Wood AL, Brusseau ML, Pilot-scale demonstration of cyclodextrin as a solubility-enhancement agent for remediation of a tetrachloroethene-contaminated aquifer, Environmental Science and Technology, 37(24), (2003), 5829-5834.

45 Fenyvesi É, Csabai K, Molnár M, Leitgib L, Gruiz K, Cyclodextrins for the enhancement of soil remediation technologie, In: Sarsby RW, Meggyes T (eds.), Construction for a Sustainable Environment, CRC Press/Balkema; Leiden, The Netherlands, 2009, pp. 197-206.

46 Molnár M, Leitgib L, Gruiz K, Fenyvesi É, Szaniszló N, Szejtli J, Fava $\mathbf{F}$, Enhanced biodegradation of transformer oil in soils with cyclodextrin from the laboratory to the field, Biodegradation, (2005), 159-168.

47 Molnár M, Fenyvesi É, Gruiz K, Illés G, Nagy Z, Kánnai P, Laboratory testing of biodegradation in soil: a comparison of chemical and biological methods, In: Gruiz K, Meggyes T (eds.), Land Contamination \& Reclamation, Vol. 17, EPP Publications Limited; UK, 2009, pp. 497-510.

48 Alef K, Estimation of microbial activities. Dehydrogenase activity, In: Alef K, Nannipieri P (eds.), Land Contamination \& Reclamation, Academic Press; London, UK, 2005, pp. 228-231. 